\title{
THE TRANSITION TO A DATA ECONOMY IN FINANCIAL SERVICES*
}

\author{
Jan Makary Fryczak \\ Lodz University of Technology, Lodz, Poland \\ e-mail:makaryjan@protonmail.com \\ ORCID: 0000-0001-6418-0256 \\ (C) 2020 Jan Makary Fryczak \\ This work is licensed under the Creative Commons Attribution-ShareAlike 4.0 International License. \\ To view a copy of this license, visit http://creativecommons.org/licenses/by-sa/4.0/
}

Quote as: Fryczak, J. M. (2020). The transition to a data economy in financial services. Financial Sciences, 25(4).

DOI: $10.15611 /$ fins.2020.4.03

JEL Classification: O300

\begin{abstract}
The aim of the article is to identify the opportunities and challenges in the field of data processing faced by companies providing financial services in Poland. Half of the world's consumers are surrounded by data collection devices. Financial services are becoming increasingly aware of the need to change to enter this new data-driven economy. This transformation is a complex process that will require the best management skills to be successful. Obviously, companies should remain as innovative as possible, but at the same time they cannot devote all their resources to investments in technology. This article reviews the literature on the current developments in data-driven technologies to provide an outline of the environment to which financial firms need to adapt. The author describes the sources from which data can be obtained, and gives examples of opportunities they create, namely autonomous cars, geolocation and targeted advertising, as well as offers insights into the challenges of data processing and the transition to a data economy.
\end{abstract}

Keywords: Big Data, Internet of Things, datafication, technological change.

\section{Introduction}

Data collecting devices surround nearly everybody: smartphones, smartwatches, autonomous cars, smart locks, light bulbs, sensors and much, much more. It is estimated that there are approximately 50 billion devices connected to the Internet of Things in the world (Hassan, Qamar, Hasan, Aman, \& Ahmed, 2020). Most of these devices collect or process data about the physical world and about consumers. These are huge amounts of data, offering an economic potential that is only just beginning

* This work is supported by the National Science Centre in Poland (NCN) under research grant no. 2019/35/B/HS4/03800 entitled The evolution of corporate reporting language: textual-analysis with computer methods. 
to be explored by financial companies. According to information from the European Commission (2020), one in five enterprises uses advanced data processing technologies. The real economy is changing, so how can financial services respond to such changes?

The aim of the study is to determine what opportunities and challenges lie before financial services companies. The article complements the literature on strategic changes that companies increasingly face when making decisions about switching to data-driven business. Being up-to-date requires serious investment from companies in new technologies and data processing capabilities. Naturally, not all investments turn out to be profitable (Dobija, Klimczak, Roztocki, \& Weistroffer, 2012). Mikalef (Mikalef, Pappas, Krogstie, \& Giannakos, 2017) outlines some guidelines for the successful datafication of companies that motivates this article. They argue that companies need to learn how to manage data resources from acquisition, through their use, to liquidation. They must be selective, so as to use data in the areas that promise greatest returns, rather than areas where data are easily available. This approach should help in the transition to a data economy.

What is a data economy anyway? Within the meaning of this article, this refers to the concept of using BigData to accelerate the work of the enterprise and the efficiency of the product for its users. Taking into account the technologies currently available, data processing itself is not a major problem such as the cost of investing in BigData and the difficulties in transforming an existing company so that there is no catastrophe during the transformation process. In the following sections of the article, the author looks at the possibility of collecting data, their exemplary use and the problems caused by data processing itself.

The structure of the article is as follows. The next section describes the sources of data available to companies. The third section explains how these data can be used. The fourth section examines the use of data-based technologies in the financial sector. The fifth section outlines scenarios for the data-driven economy of the future, whilst the final section offers some conclusions.

\section{Sources of data}

Data processed by companies do not come out of thin air. Europe has created a world standard for the care of personal data and its security, the General Data Protection Regulation, or GDPR (UE 2016/679), while California and Japan (Żyrek, 2020) are introducing similar legal solutions. Personal data are not the only type used en masse, data about companies and their production activities are non-personal, although certainly the most valuable one. Data used to build big datasets are anonymized, and then processed and used to predict trends and find relationships in society. Importantly, data collecting companies are not concerned with collecting high-quality data about specific individuals (Ghasemaghaei \& Calic, 2019), but what they use are massive customer data obtained from millions of users and then subjected to statistical processing. 
Collecting large amounts of data has become possible in recent years thanks to the development and popularization of smartphones and related personal devices. These devices are equipped with a set of sensors that collect data about the users and their environment. Every smartphone is fitted with a microphone, and for example, a GPS and a gyroscope. Moreover, app developers can obtain permission from users to access data from other apps on the same device. Currently, data can be gathered from 5.2 billion mobile phone users (DataReportal, 2020). According to GSM Association real-time intelligence data, today there are 5.23 billion people that have a mobile device. This means that $66.79 \%$ of the world's population use a mobile device. Moreover, according to Statista, the current number of smartphone users worldwide is 3.5 billion (Statista, 2020b). This means that $44.87 \%$ of people own a smartphone. The stream of data generated by devices is therefore of an unprecedented size and continues to grow as devices are increasingly popular and the range of telecommunications networks is being extended (Statista, 2020a).

The connection of devices to the Internet enables the collection of data by tracking activity with tracker files, called cookies (Soltani, Canty, Mayo, Thomas, \& Hoofnagle, 2009). European regulations require websites to inform users about tracking, but this is not the norm in other regions of the world. Cookies help to optimize the website design process by identifying individual users. For example, cookies allow a website to display advertisements for products based on the users' interests, purchase history and place of residence. Thanks to cookies, the user does not constantly see the same advertisement. Cookies also help in shopping, allowing the website to 'remember' the goods put in the digital basket and navigate through the store without having to $\log$ in to each subpage. Thus cookies exemplify the common characteristic of the connected world: users are being tracked while benefiting from a useful technology, and the data they generate are collected and used for purposes beyond their control (Degeling et al., 2018).

At the same time data are collected using traditional methods such as forms. This is a tedious method, compared to automated data collection from devices, and later data standardization to organize responses in a unified database (European Commission, 2020). Fast form filling on the Internet facilitates this process compared to its paper counterpart. For example, online service providers offer their customers the option of subscribing to a 'free' newsletter. If the form filled in by the customer on the occasion is well thought-out, it can be a great source of information enriching the customer database. People who decide to subscribe to the newsletter are probably already interested in the offered product and there is a high probability that they will use it in the future. Forms are commonly filled in by clients of financial institutions before they can be offered insurance, investment or banking products. 


\section{Using data}

Targeted advertising is where the bulk of data processing efforts are placed (Lau, 2020). Currently, the main provider of this type of advertising is Google Ads (formerly AdWords). The essence of Google Ads is to support the marketing activities undertaken by clients through the Google search engine. Modern technologies provide the opportunity to specifically target a group. Advertisements are displayed to users who are most often already searching for a given product or service. A wellprepared ad should encourage potential customers to click, and discourage people who are not interested in the specific product or service, so that clicking them does not generate an unnecessary cost. This is because the advertiser is charged per click, not per view or impression. The rates for one click range from a few cents to a dollar or more (WIWI, 2020). The strength of Google Ads is that their results are fully measurable. Advertisers can easily compare the advertising expenditure and the revenue generated thanks to it. The ease of using Google Ads is increased by integrating the service with Google Analytics, thanks to which customers can check what exactly happened before and after a user clicks an ad. This increases the ability to optimize advertising activities.

Targeted advertising gives financial companies completely new opportunities to reach potential customers. Indeed, they are concentrating their budgets on the Internet and away from traditional media. What is more, they can adjust advertising expenditures and manage them virtually overnight, depending on the results. In the long run, such a possibility should convince even those enterprises that have so far attempted to reduce advertising budgets or have not decided to advertise on the Internet at all, especially since the more entities advertise on the Internet, the less clout they carry and the more they are willing to pay for an attractive and effective campaign. The companies behind tools such as Google Ads or Facebook ads are global giants who have invested billions of dollars in the development of technologies that are not comparable to any products known before.

Location data are the second most easily generated and used type of information (Mayer-Schoenberger \& Cukier, 2013). There are several satellite navigation systems, the most popular being the American Global Positioning System. Other countries have implemented their own solutions: Europe launched Galileo, China Beidou, France DORIS, Japan QZSS and Russia GLONASS. Satellite navigation technology was originally developed for the military, and only years later was it made available to the public. Nowadays these systems are free and available to anyone who has a receiver. GPS vehicle tracking systems bring measurable benefits, including cost savings and effective vehicle performance management. The system helps choose the right route and reduce the fuel cost of the trip. Thanks to the advanced reports and analyses that one can constantly receive, it is easy to assess the effectiveness of working time while performing official duties. 
In addition to dedicated receivers used specifically for tracking and locating, such receivers are found in virtually every smartphone. Moreover, location data is available not only to the user who generates it. They may also be visible to the developers of the app the user of which has allowed access to location data. This combination gives great opportunities to track not only the location, but also the specific behaviour of potential customers. A properly designed application can be used to monitor the safety of children or the elderly. The constant overview of the location of a loved one makes it possible to check whether something unexpected has happened and whether help is needed. A natural extension for financial services are automatic loss detection and its management by insurance companies.

Furthermore, in conjunction with data on finances or purchasing preferences, it is possible to recommend specific stores or locations, i.e. geotargeting. Targeting ads to geographic locations is possible in Google Ads. When planning ads, companies have several geotargeting options available, thanks to which they can display ads to selected users in preferred locations. Companies can choose a specific country, region or area around the selected location. Facebook also allows geotargeting, where by default an advertiser can choose a specific country, province or city, but it allows the location to be determined with precision. For example, ads may target people who have recently been in the vicinity of the bank's branch or a competitor's branch.

The infrastructure of the location system itself is very expensive. The service life of satellites is now estimated at around 8-11 years, which means that they have to be constantly replenished when worn-out. In this context, the greatest advantage of satellite navigation systems is that they are available for free worldwide, much like road infrastructure. In some cases, the user does not even need to buy a receiver to use the data efficiently. It is enough to gain access to data generated by potential customers who have an app installed in their smartphone. Therefore, it is possible to access very large data sets, while maintaining low access costs.

Autonomous cars are a technology that promises to revolutionize transport, and car insurance along with it. This is possible thanks to a combination of several modern technologies. According to Polish law on road traffic, an autonomous car is "a motor vehicle equipped with systems that control the movement of the vehicle and enable its movement without the driver's interference, who can take control of the vehicle at any time." There are several classes of car autonomy (Ondruš, Kolla, Vertal', \& Šarić, 2020):

Class 0 - no autonomy. For example, an older generation car with cruise control, ABS or APS uses technology to help a human driver in following his or her decisions.

Class 1 - driver support when driving on a highway or expressway. Accelerates and decelerates independently to match their speed to the vehicle in front and to keep in lane.

Class 2 - partial automation and extension of Class 1 . The car can take control of the steering wheel in certain situations. 
Class 3 - conditional automation. The car can take control of driving under certain conditions, such as parking. The car itself observes the surroundings using sensors and vision systems and no longer supports the driver but drives the car. However, the driver must always remain alert and be ready to take control in an emergency.

Class 4 - advanced automation. The car controls the entire vehicle. It is also prepared to react independently in emergency situations. This means that the driver sitting inside - despite appropriate announcements - may not take control in an emergency.

Class 5 - full automation. A car that does not require a driver's presence and does not even need to have any steering instruments installed.

For independent driving however, the on-board computer requires a huge amount of information from sensors located throughout the car. These include: radars devices that search for objects using radio waves; 'lidars' - devices that works similar to radar but uses laser light instead of radio waves; a satellite navigation system, most often a GPS receiver, that provides position information on the basis of radio signals sent from space; cameras that enable computer vision, which involves the processing of an image by a machine into a digital description through the use of vision systems for further use by a computer. An ordinary car can be equipped with up to 200 sensors, which in everyday use generate up to $1 \mathrm{~TB}$ of data per day (Johnson, 2018).

Such technology allows in the long run to reduce the costs of transporting people and cargo, while eradicating driving errors caused by human inattention or bravado. Perhaps this would reduce, among other things, the number of road accidents. If successful, this would mean an overall improvement in the safety of the road transport industry and the cost of maintaining it. Autonomous cars also make it possible to use the time normally spent driving as normal working time. All the passenger's attention could remain focused on issues related to work or making important calls, rather than on driving. As a result, enterprises would avoid paying highly skilled workers for purely manual work.

\section{Data in financial services}

The financial industry has extensive experience in collecting data. For years, financial companies have built internal high-quality databases waiting for internal use or sale outside the company. Opportunities to generate value by selling data are limited, however, as the necessary anonymization of such data greatly reduces their value and usability. The sharing of data itself is also quite problematic due to the regulations on sharing, processing and protecting data. Banks, for example, have an unprecedented wealth of data about their customers, ranging from complete personal and financial data, through account activity, made on the transaction website or mobile payment app. At this point, such data can be used, among others, to better target specific 
financial products for specific customers. For example, it is possible to offer extreme sports insurance to a client who has recently purchased professional diving or skiing equipment.

Forms are one of the least loved elements of interaction between financial services and their clients. Automation helps reduce this burden. In recent years, many countries have seen an increased interest in pre-filled forms (European Commission, 2020). In Poland, the government made the biggest contribution to increasing this indicator by introducing pre-completed tax returns. In recent years, Poland has improved its results in the use of pre-filled forms and the provision of services via the Internet, and in terms of the use of open data ranks above the EU average (European Commission, 2020). The government and financial institutions have long had access to huge databases of citizen and customer data. Pre-filled forms are currently one of the few ways to skilfully use these datasets. Thanks to this, citizens save time and generate fewer errors caused by inattention, and the state does not have to subsequently correct these errors, thus reducing processing costs.

Financial companies can enter transactions with data brokers to sell or purchase data. Consequently, data do not need to be used immediately in a creative way. There are many other entities that have developed different ways of using our data. Such companies may want to buy data to enrich their database on existing customers with new characteristics. In this case, it is enough to systematize the collected data in the manner required by the client. The value of data increases when other companies use previously collected data in a much more creative way (Klimczak, 2021). Combining customer conversation records and their entries in social media, for example, can increase the effectiveness of chatbots or virtual agents used by banks. Data markets in the United States operate on this principle. Unfortunately, sometimes it is possible to identify people based on previously anonymised data, leading to unethical situations. In the USA, the federal and state governments are already taking the first steps to reduce data consumption, gradually withdrawing from the almost complete freedom enjoyed by American enterprises. For example, in 2019 the State of Vermont enacted a law requiring registration by companies engaged in the collection and trading of data.

Financial companies in Poland face significant challenges in developing their data-based competencies. DESI, the Digital Economy and Society Index, measures the level of digital productivity (European Commission, 2020). According to the report, Poland ranks 23rd with a score of 45.0 compared to the 28 EU Member States with an average of 52.6. Almost half of Polish citizens do not have basic digital skills, and about $15 \%$ do not use the Internet at all. The skills of using computers, the Internet, and related technologies by Poles remain at a low level compared to the European Union average. Only 44\% of Poles aged 16-74 have at least basic digital skills, and specialists in the field of ICT (Information and Communication Technologies) constitute only $3 \%$ of Polish society. This implies the lack of a sufficient number of specialists who could improve the situation in enterprises, hence 
most of them do not use modern technologies such as cloud services or social media. Enterprises at a low degree of digitalization constitute as much as $60 \%$ of the market, and only $11 \%$ companies are highly digitalized. Internet sales are conducted by $13 \%$ of enterprises from the SME sector, of which 5\% conduct foreign sales to clients from other EU countries. Only 7\% of enterprises use the cloud, and 8\% work with BigData. In these categories, innovative companies with a short history in the market, i.e. start-ups, are relatively better.

The situation in the European Union is better than in Poland (European Commission, 2020). Basic digital skills are possessed, on average, by $58 \%$ of the population. ICT specialists account for 3.9\% of the labour market. Enterprises with a low degree of digitalization constitute $39 \%$ of the market, while highly digitalized enterprises account for $26 \%$ of the market. Internet sales are conducted on average by $18 \%$ of enterprises from the SME sector, of which $8 \%$ conduct foreign sales to clients from other EU countries, including Poland. As many as $18 \%$ of enterprises use the cloud, and $12 \%$ work with BigData.

Poland is gradually increasing its level of digitization, however other member states are doing the same. In order to catch up with the leaders, Poland needs to accelerate the development and research on the use of information technologies in financial enterprises. One of the biggest challenges may be the lack of qualified staff, which is already a development bottleneck in the SME sector.

\section{The data economy}

The current level of development of work on data sets and the speed of the development of technologies cooperating with BigData indicate huge opportunities related to the analysis of the data stream in real time, however these technologies will require new data transfer solutions. For example, according to data from IAV $\mathrm{GmbH}$ (BankMyCell, 2020), a single autonomous car produces up to 15 terabytes of data per hour. Storage drives with a capacity of 128 to 2048 GB that are usually installed in computers and laptops sold today would be full within a couple of minutes. The transfer of such amounts of data would literally clog up the mobile telecommunications network, especially in the event of an increase in the number of cars fitted with autonomous driving devices. Hence, investments in the development of $5 \mathrm{G}$ technology offering transmission speeds of up to $20 \mathrm{~Gb} / \mathrm{s}$ are a key infrastructural technology.

The 5G telecommunications network is currently under construction in Poland. Transmission speeds of about $400-500 \mathrm{Mb} / \mathrm{s}$ are becoming available in major cities (Duda, 2020). The introduction of 5G technology to widespread use, and in the future $6 \mathrm{G}$ (estimated speed $\sim 95 \mathrm{~Gb} / \mathrm{s}$ ), will enable the introduction of fully autonomous cars. With sufficient data the cars can communicate with each other to avoid collisions and accidents. The technology can also benefit the online mapping 
industry. Real-time data from cars and from phones located in cars can be used to create real-time traffic jam maps. As a result, the systems will be able to better estimate travel times and intelligently predict the possibility of traffic jams before the cars are lined up, one after the other, and cannot move. Combined with autonomous cars, this will reduce fuel or electricity consumption. Technology for the computer recognition of traffic signs is also needed. The proliferation of the autonomous car business activity could change the perception of public transport, which could focus on making more smaller cars available through carsharing, rather than large vehicles for mass transport. What will definitely change is car insurance, the most important line of insurance products today.

These changes are likely to differ depending on the country/region of introduction. This is due to the differences in the insurance systems between countries. In Poland, for example, civil liability insurance is purchased for a specific car, and the information about a specific driver contained in the contract is optional and most often relates to age or experience. However, there are countries where insurance is purchased on the driver, who can therefore drive virtually any vehicle. In the situation of the popularization of autonomous cars, it is the software, not the driver, that will be responsible for the safety of passengers and the environment around the car (Margan, 2018). It is therefore difficult to speculate about insurance based on the age or experience of the driver, if the driver might not even be behind the wheel of the vehicle. Such a situation would require the reconstruction of the entire insurance system, which would be based on the quality of the software and the sensors built into the car. Until an agreement on liability is reached on autonomous cars, it will be difficult to establish liability as the control of the vehicle varies between the manufacturer, driver, software provider, etc. Insurance for such a car could be passed on to the manufacturers who in turn would pass it on to customers in the form of annual fees. Properly-functioning software could lead to a decrease in the number of accidents, which could also lead to a total change in the automotive market. Any innovative changes create challenges that the industry will have to face in the coming years.

In future, digitalization may lead to changes in decision-making in financial enterprises, where highly-paid specialists can be replaced by self-learning algorithms using Big Data (McAfee\& Brynjolfsson, 2012). The notion of transferring responsibility from human decision-makers to automata raises many doubts, however (Newell \& Marabelli, 2015). Organizational and social inertia will probably reduce the pace of technology adoption significantly. Nevertheless, the replacement of humans with algorithms in the majority of routine tasks appears to be inevitable.

To sum up, the balance of the benefits and costs of digitalization is a multidimensional problem, and the profitability of the implemented solutions depends on many factors. A tendency can be noticed that most of the technologies used now were being developed over many years, and are the work of corporate 
giants who, based on these projects, have earned their place on the market. A perfect example of this is Google with the most popular search engine in the world accounting for $92.71 \%$ of the search market (StatCounter, 2020), which took decades to perfect. Companies that cannot afford and sustain multi-million investments in research and technology development are forced to use ready-made solutions proposed by larger enterprises. Naturally, the providers of these solutions capture most of the value generated from data.

\section{Conclusion}

This article outlines the global progress of digitalization and its impact on financial services by looking at sources of data, their potential applications, and the emergence of a data economy. It reviews the opportunities and challenges that lie ahead for the financial services industry in the context of the global transition to a data economy. The opportunities include technologies for targeting services to clients that may need them, using data on consumer activities. This begins with advertising and client acquisition, but also with offering services to existing clients on the basis of realtime data so that a personalized offer can be presented when and where the client needs it. Speeding up the sales process with pre-filled forms and replacing lengthy bureaucratic decision-making processes with algorithms are some of the applications. Furthermore, the spread of mobile devices has led to the emergence of new IoTbased products whose potential has not yet been fully realized in financial services. Similarly, the trend towards autonomous and driverless cars signals a profound change in the insurance market. Moreover, the sector itself is being challenged as financial companies face stiff competition from global Internet giants who control the bulk of international data flows and capture most of the value generated from the data they process. Consequently, financial service companies need to focus on arranging their own resources in novel and profitable ways. In the case of Poland, the main challenge lies in creating a technically qualified workforce capable of carrying out this transformation.

\section{References}

BankMyCell. (2020). How many smartphones are in the world? Retrieved from https://www.bankmycell.com/blog/how-many-phones-are-in-the-world

DataReportal. (2020). Digital 2020: October GLOBAL STATSHOT. Retrieved from https://datareportal. com/reports/digital-2020-october-global-statshot

Degeling, M., Utz, C., Lentzsch, C., Hosseini, H., Schaub, F., \& Holz, T. (2018). We value your privacy... now take some cookies: Measuring the GDPR's impact on web privacy. Preprint arXiv:1808.05096.

Dobija, D., Klimczak, K. M., Roztocki, N., \& Weistroffer, H. R. (2012). Information technology investment announcements and market value in transition economies: Evidence from the Warsaw 
Stock Exchange. Journal of Strategic Information Systems, 21(4), 308-319. Retrieved from https://doi.org/10.1016/j.jsis.2012.07.003

Duda, T. (2020). Jak szybki jest Internet $5 G$ w sieci Plus? Sprawdzam. Retrieved from https://www. benchmark.pl/testy_i_recenzje/jak-szybki-jest-internet-5g-w-polsce-realne-pomiary-w-miastach. $\mathrm{html}$

European Commission. (2020). The Digital Economy and Society Index (DESI) 2020. Retrieved from https://ec.europa.eu/digital-single-market/en/digital-economy-and-society-index-desi

Ghasemaghaei, M., \& Calic, G. (2019). Can big data improve firm decision quality? The role of data quality and data diagnosticity. Decision Support Systems, (120), 38-49. doi:10.1016/j. dss.2019.03.008

Hassan, R., Qamar, F., Hasan, M. K., Aman, A. H. M., \& Ahmed, A. S. (2020). The Internet of Things and its applications: A comprehensive survey. Symmetry, 12(10), 1674. Retrieved from https:// www.mdpi.com/2073-8994/12/10/1674/pdf

Johnson, M. (2018). The business case for a data refinery. Scientific American. Retrieved from https:// blogs.scientificamerican.com/observations/the-business-case-for-a-data-refinery/

Klimczak, K. M. (2021). Text analysis in finance: The challenges for efficient application. In J. Monkiewicz, \& L. Gąsiorkiewicz (Eds.). Innovation in financial services: Balancing public and private interests (pp. 199-216). Routledge.

Lau, Y. (2020). A brief primer on the economics of targeted advertising. Economic Issues. Bureau of Economics. Federal Trade Commission.

Margan, S. K. (2018). Autonomous vehicles and insurance. BimaQuest: The Journal of Insurance \& Management, 18(3), 15-24.

Mayer-Schönberger, V., \& Cukier, K. (2013). Big Data: A revolution that will transform how we live, work, and think. London: John Murray Publishers.

McAfee, A. \& Brynjolfsson, E. (2012). Big Data: The management revolution. Harvard Business Review. Retrieved from https://hbr.org/2012/10/big-data-the-management-revolution

Mikalef, P., Pappas, I. O., Krogstie, J., \& Giannakos, M. (2017). Big Data analytics capabilities: A systematic literature review and research agenda. Information Systems and e-Business Management, 16(3), 547-578. doi: 10.1007/s10257-017-0362-y

Newell, S. \& Marabelli, M. (2015). Strategic opportunities (and challenges) of algorithmic decision-making: A call for action on the long-term societal effects of 'datification'. The Journal of Strategic Information Systems. 24(1), 3-14. doi:10.1016/j.jsis.2015.02.001

Ondruš, J., Kolla, E., Vertal', P., \& Šarić, Ž. (2020). How do autonomous cars work? (Transportation Research Procedia No. 44, pp. 226-233).

Soltani, A., Canty, S., Mayo, Q., Thomas, L., \& Hoofnagle, C. J. (2009). Flash cookies and privacy (SSRN Working Paper No. 1446862). doi:10.2139/ssrn.1446862

StatCounter. (2020). Search engine market share worldwide. Retrieved from https://gs.statcounter.com/ search-engine-market-share

Statista. (2020a). Forecast number of mobile users worldwide from 2020 to 2024. Retrieved from https://www.statista.com/statistics/218984/number-of-global-mobile-users-since-2010/

Statista. (2020b). Number of smartphone users from 2016 to 2021. Retrieved from https://www.statista. com/statistics/330695/number-of-smartphone-users-worldwide/

WIWI. (2020). Ile kosztuje reklama w Google Ads (dawniej Google AdWords)? Retrieved from https:// www.pozycjonusz.pl/ile-kosztuje-reklama-w-google-ads-adwords/

Żyrek, A. (2020). CCPA, czyli ochrona danych osobowych w Kalifornii. Retrieved from https://www. parp.gov.pl/component/content/article/63647:ccpa-czyli-ochrona-danych-osobowych-wkalifornii 


\section{PRZEJŚCIE DO GOSPODARKI OPARTEJ NA DANYCH W USEUGACH FINANSOWYCH}

Streszczenie: Cel artykułu to identyfikacja szans i wyzwań stojących przed firmami świadczącymi usługi finansowe w Polsce w zakresie przetwarzania danych. Połowa konsumentów na świecie jest otoczona urządzeniami do zbierania danych. Sektor usług finansowych jest coraz bardziej świadomy potrzeby zmian, aby stać się częścią gospodarki opartej na danych. Ta transformacja jest złożonym procesem, wymagającym najlepszych umiejętności zarządzania, aby odnieść sukces. Przedsiębiorstwa powinny być jak najbardziej innowacyjne, ale jednocześnie nie mogą przeznaczyć wszystkich swoich zasobów na inwestycje w technologię. W artykule dokonano przeglądu literatury na temat aktualnego rozwoju technologii opartych na danych, aby przedstawić zarys środowiska, do którego firmy finansowe muszą się dostosować. Opisano źródła, z których można pozyskiwać dane, i podano przykłady stwarzanych przez nie możliwości. Omówiono takie kwestie, jak: autonomiczne samochody, geolokalizacja oraz reklama celowana. Zaprezentowano przegląd wyzwań związanych z przetwarzaniem danych oraz przejściem do gospodarki opartej na danych.

Słowa kluczowe: Big Data, Internet rzeczy, danetyzacja, zmiana technologiczna. 